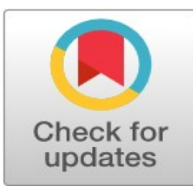

PRIMARY RESEARCH

\title{
Applying Polya's four-steps and Schoenfeld's behavior categories to enhance students' mathematical problem solving
}

\author{
Yuwalee Thiangthung * \\ International College, Suan Sunandha Rajabhat University, Bangkok, Thailand
}

\author{
Key Words \\ Problem solving \\ Polya's four-steps \\ Schoenfeld's behavior categories \\ attitude
}

Received: 15 May 2016

Accepted: 16 July 2016

Published: 27 October 2016

\begin{abstract}
The purposes of this action research were to enhance student's ability in solving mathematical problems by applying Polya's Four-Steps in problem-solving (understanding problem, devising a plan, carrying out the plan, and looking back) and Schoenfeld's Behavior Categories (resources, heuristics, control, and belief systems), and to investigate students' attitude towards mathematical problem-solving The topics used in this study were principles of counting and probability. The participants were 35 Grade 11 students from a mathematics class at a secondary school in Bangkok, Thailand, studying in the second semester of 2015. The research instruments were 11 lesson plans on principles of counting and probability, two summative tests, and an attitude questionnaire on mathematical problem-solving. Te aching and learning lasted for 13 periods, with 50 minutes in each period. There were three cycles of action plan (plan, do check, and reflect). The problem-solving techniques from the two authors were integrated into each lesson. Data were collected and analyzed from tests, students' homework, teacher's-reflection, and attitude questionnaire. The results revealed that $80.19 \%$ of all students passed both summative tests in problem-solving. More than $93 \%$ of students applied Polya's steps 1, 2, and 3 in solving problems, but only $42.80 \%$ of students applied step 4. About $91 \%$ of students applied Schoenfeld's Behavior Categories, especially resources and heuristics. For the attitude questionnaire using the Likert Scale, the researcher divided it into three categories as follows: 1) Positive feeling towards mathematical problem solving, 2) Negative feeling towards mathematical problem solving, and 3) Applying Polya's Four-Steps and Schoenfeld's Behavior Categories. Most students showed positive feelings in the first category to solve mathematical problems $(\bar{x}=3.66$, SD $=1.18$ ). In the second category, the majority of students disagreed with this category. A few students felt uncomfortable solving mathematical problems $(\bar{x}=2.45, S D=0.94)$. In the last category, many students applied Polya's Four-Steps and Schoenfeld's Behavior Categories $(\overline{\mathrm{x}}=3.51, \mathrm{SD}=1.06)$. The findings will help student improve their mathematical problem solving skills.
\end{abstract}

(C2016 The Author(s). Published by TAF Publishing.

\section{INTRODUCTION}

Mathematics plays an important role in the development of the human thinking. It develops creativity, logical and systematic thinking, accurate predictions, and appropriate planning. It also serves as a tool for learning science, technology and other disciplines (Bureau of Academic Affairs and Educational Standards, 2008). Solving mathematical problems is an important process students should know and develop in themselves. Learning to solve mathematical problems helps students approach variety of ideas, thinking habits, and argumentations. It is the basic skill that students can apply throughout their lives (The institute for the Promotion of Teaching Science and Technology, 2008). Problem solving has, as predicted in the 1980 Year book of the National Council of Teachers of Mathematics (NCTM) (Krulik and Rudnick, 1980), been the core theme of the year book. Position statement of NCTM in its Agenda for actions stated that "problem solving must be the focus of

\footnotetext{
${ }^{*}$ Corresponding author: Yuwalee Thiangthung

†Email: bowyu_thth@hotmail.com
} 
school mathematics" (NCTM, 1980, 1).

According to NCTM, problem is a task for which the solution method is not known in advance. In order to find a solution, students must draw conclusion from their knowledge, and through problem solving process (NCTM, 2000). Many researchers investigated ways to improve students' problem solving ability. Many textbooks and researchers suggested ways to help students. Among those, the study and suggestion from Polya (1973) and Schoenfeld (1986) are very outstanding. Polya (1973) proposed four steps in solving mathematics problems. The steps are 1) understanding problem, 2) devising a plan, 3) carrying out the plan, and 4) looking back (Polya, 1973, 5). Many teachers and publishers adopted his idea in teaching and writing textbooks. Alan H. Schoenfeld, from his insightful research about students' problem solving, concluded four important categories in solving problems. They are resources, heuristics, control, and belief systems (Schoenfeld, 1986, 44). Many teachers and educators widely accepted his study and used the categories to guide their teaching and further study.

From the class the researcher taught in the second semester of academic year 2015, the main problem was about students' problem solving in mathematics. They did not know how to start or continue to finish the problems. So, the researcher planned to help students by applying Polya's Four-Steps to be the framework and to use techniques from Schoenfeld's categories to continue their problem solving. The study was conducted in a classroom. Therefore, it was appropriate to apply action research in this study.

\section{LITERATURE REVIEW}

This section was divided into two related topics: teaching mathematical problem solving and problem posing.

\section{Teaching Mathematical Problem Solving}

Polya (1973) stated that students need intellectual courage, intellectual honesty and wise restraint when they solve problems. Students can develop these traits by being exposed to problem solving activities in class which help students develop a better understanding of mathematics and become better problem solvers. Polya (1973) presented four steps in problem solving (understanding problem, devising a plan, carrying out the plan, and looking back). However, in step two, Polya (1973) did not describe clearly how to plan. Therefore, the researcher integrated Schoenfeld's Behavior Categories in step 2 for achieving and enhancing students' problem solving ability.

From Schoenfeld's (1986) research, he discovered that knowledge and behaviors are necessary for mathematical problem solving. He presented four categories as follows: 1) Resources (mathematical knowledge possessed by the individual that can be brought to bear on the problem at hand), 2) Heuristics (strategies and techniques for making progress on unfamiliar or nonstandard problems; rules of thumb for effective problem solving), 3) Control (global decisions regarding the selection and implementation of resources and strategies), and 4) Belief Systems (one's "mathematical world view", the set of determinants of an individual's behavior).

Kopka (2013) argued that using the framework is not the only component in solving problems but it depends on the nature of problems, alternative ways to approach the problems. He suggested the strategies in solving problems as follows: 1) Strategy of analogy, 2) Guess - check - revise, 3) Systematic experimentation, 4) Problem reformulation, 5) Solution drawing, 6) Working backwards, and 7) Use of graphs of functions. 


\section{Problem Posing}

Strategies used for solving mathematical problem are not only one component to improve students' problem solving ability, but problem posing is also recognized as an important component of mathematics teaching and learning, especially mathematical problem solving (NCTM, 2000). Teachers will gain knowledge and confidence when they incorporate problem posing activities in their classes. While experiencing problem posing, teachers will acknowledge its various benefits. Such experiences should start by the time those teachers are being qualified towards their profession.

Ban-Har and Berinderjeet (1999) suggested the generation of new problems or the reformulating of existing ones. It is recognized as a valuable process that is motivating, challenging and allows students to exercise their creativity and independent learning skills. Ban-Har and Kaur used a problem posing task requiring students to pose problems based on a given set of facts. They established a framework which they called nodal framework for analyzing the correctness and complexity of the problems formulated. They found out that students who were unable to detect contradictions provided in their problems were consistently unable to solve non-routine problems. There was no clear correlation between the ability to pose good problems and the ability to solve problems.

Bernardo (1998) used a strategy in problem posing that promotes analogical transfer among high school students. They were given various types of basic probability problems. Students in the experimental group were asked to make their own problems similar to the ones they studied. Suggestions on objects and events they can use in the problems were given. The study showed that students who were taught problem construction strategy were better at solving the analogous word problems. One such instructional strategy that promotes analogical transfer involves presenting students with a context problem and then asking them to make their own problem using a different context. The effectiveness of this strategy, according to Bernardo, seems to be due to the deeper level of understanding of the problem structure achieved by the problem solver.

\section{Research Objectives}

1: To enhance students' ability in solving mathematics problems by applying Polya's FourSteps and Schoenfeld's Behavior Categories in solving mathematics problems. 2: To investigate students' attitude towards mathematical problem solving based on the approach of Polya's Four-Steps and Schoenfeld's Behavior Categories. For the first objective, the researcher aimed at least $70 \%$ of all students in the class to pass the problem solving tests, summative test I and II. The criterion for each student to pass the tests is to gain at least $70 \%$ of each test. For the second objective, the researcher aimed students to gain positive attitude towards mathematical problem solving. The researcher also used students' homework, worksheets, and teacher's reflection to consider students' problem solving progress.

\section{METHODOLOGY}

Participants

The participants in this study were 35 Grade 11 students from a classroom that the researcher taught in the second semester, academic year 2015 at a secondary school in Bangkok, Thailand.

\section{Research Instruments}

The instruments used in this study were lesson plans, summative test I, summative test II, an attitude questionnaire, students' homework, worksheets, and teacher's reflection. There were 11 lesson plans on principle of counting and probability by integrating Polya's 
Four-Steps and Schoenfeld's Behavior Categories in solving mathematics problems. Details of lesson plans were shown in Table 1.

TABLE 1. Mean scores of two summative tests and the number of students who passed each test

\begin{tabular}{lll}
\hline \hline Lesson Plans No. & Content & Period (50 minutes) \\
\hline 1 & Basic counting theorems: Multiplication principle & 1 \\
\hline 2 & Basic counting theorems: Addition principle & 1 \\
\hline 3 & Word problems about counting & 1 \\
\hline 4 & $\begin{array}{l}\text { Factorial } \\
\text { Reflection }\end{array}$ & 1 \\
& Summative test I & 1 \\
\hline 5 & Random experiments & 1 \\
\hline 6 & Sample spaces & 1 \\
\hline 7 & Events & 1 \\
& Reflection 2 & \\
\hline 8 & Definition of probability & 1 \\
\hline 9 & Word problems about probability & 1 \\
\hline 10 & Probability of events & 1 \\
& Reflection 3 & 1 \\
\hline 11 & Word problems about probability of events & 1 \\
\hline Total & Summative test II & $\mathbf{1 3}$ \\
\hline \hline
\end{tabular}

Table 2 showed mean scores of two summative tests. In summative test I, mean score was 11.60 ( $\mathrm{SD}=2.103$ ). Twenty five students passed the test which was 71.43 percent. In summative test II, mean score was 12.46 (SD = 1.336). Thirty three students passed the test which was 94.29 percent. Mean score of both summative tests was 24.06 (SD = 1.801). So, more than 70 percent of students passed both summative tests as required by the researcher.

Table 1 showed contents and time to spend in each lesson plan with four steps in teaching. The steps included 1) Reviewing previous knowledge 2) Introducing new content and examples , 3) Solving problem by using Polya's Four-Steps (understand the problem, devise a plan, carry out the plan, look back) and Schoenfeld's Behavior Categories (resources, heuristics, control, and belief systems), and 4) Conclusion at the end of each period. After that, the researcher reflected students' behaviors and results for improvement in the next period. The researcher investigated students' problem solving ability from the results of both summative tests.

Summative test I consisted of ten multiple choice items and three written items.

Summative test II consisted of seven word problems which were written items.

Students' attitude questionnaire towards mathematical problem solving consisted of 12 items which were divided into three categories developed by the researcher.

In analyzing tests and attitude questionnaire, the researcher used Index of Item Objective Congruency (IOC) to consider congruence between test items and their objectives. IOC was calculated by the formula (Arreerard, 2009, 132).

$\mathrm{IOC}=\frac{\sum R}{N}$

IOC means the congruence between test items and their objectives.

$\Sigma$ means the total scores of congruence given by expert in each item. 
$\mathrm{N}$ means the total number of experts.

The values of IOC in summative test I, summative test II, and attitude questionnaire were $0.949,1.00$, and 0.872 respectively.

Attitude of Grade 11 students towards mathematical problem solving based on the approach of Polya's Four-Steps and Schoenfeld's Behavior Categories was analyzed by mean $(\bar{x})$, standard deviation $(\mathrm{SD})$, and categories.

The levels for attitude evaluation were 5-point Likert scales [5];

5 means Strongly Agree

4 means Agree

3 means Undecided

2 means Disagree

1 means Strongly Disagree

Students' handouts, homework and worksheets were distributed at the end of each period. Teacher's reflection was also recorded.

\section{Data Collection}

The data were collected from summative tests, students' questionnaire and teacher's reflection. During each period, the researcher implemented teaching processes by integrating Polya's Four-Steps and Schoenfeld's Behavior Categories. The participants took summative test I after period 4 and summative test II in the final period. In each period, the researcher observed students' behaviors in solving problems from exercises, homework, and worksheets. After period 13, students took attitude questionnaire.

\section{RESULTS}

The people and organizational bodies category describes the stakeholders who make and enforce the rules defined above, and includes components such as data stakeholders, a data governance office, and data stewards. The processes category denotes proactive, ongoing processes that people follow to govern data.

\section{Mean Scores of Two Summative Tests}

TABLE 2. Details of lesson plans

\begin{tabular}{lllllll}
\hline \hline $\begin{array}{l}\text { Summative } \\
\text { Tests }\end{array}$ & $\mathbf{N}$ & $\begin{array}{l}\text { Total } \\
\text { Score }\end{array}$ & $\begin{array}{l}\text { 70 percent } \\
\text { of total score }\end{array}$ & Mean & $\begin{array}{l}\text { SD } \\
\mathbf{x}\end{array}$ & $\begin{array}{l}\text { Number of passing } \\
\text { students (percent) }\end{array}$ \\
\hline Test I & 35 & 15 & 10.5 & 11.60 & 2.103 & $25(71.43)$ \\
\hline Test II & 35 & 15 & 10.5 & 12.46 & 1.336 & $33(94.29)$ \\
\hline Total & $\mathbf{3 5}$ & $\mathbf{3 0}$ & $\mathbf{2 1}$ & $\mathbf{2 4 . 0 6}$ & $\mathbf{1 . 8 0 1}$ & \\
\hline \hline
\end{tabular}

Table 2 showed mean scores of two summative tests. In summative test I, mean score was 11.60 ( $\mathrm{SD}=2.103$ ). Twenty five students passed the test which was 71.43 percent. In summative test II, mean score was $12.46(\mathrm{SD}=1.336)$. Thirty three students passed the test which was 94.29 percent. Mean score of both summative tests was 24.06 (SD = 1.801). So, more than 70 percent of students passed both summative tests as required by the researcher.

\section{Steps used by Students in Summative Test II}

Table 3 showed students' scores of each written item in summative test II which was di- 
TABLE 3. Steps in summative test II (written items) expressed by students

\begin{tabular}{llllllll}
\hline \hline $\begin{array}{l}\text { Summative } \\
\text { Test II }\end{array}$ & $\begin{array}{l}\text { Understanding } \\
\mathbf{( 0 . 5 )}\end{array}$ & $\begin{array}{l}\text { Planning } \\
\mathbf{( 0 . 5 )}\end{array}$ & $\begin{array}{l}\text { Devising a plan } \\
\mathbf{( 0 . 5 )}\end{array}$ & $\begin{array}{l}\text { Looking back } \\
\mathbf{( 0 . 5 )}\end{array}$ & $\begin{array}{l}\text { Total } \\
\text { Score }\end{array}$ & $\begin{array}{l}\text { Mean } \\
\text { Score }\end{array}$ & $\begin{array}{l}\text { Percentage of } \\
\text { Mean Score }\end{array}$ \\
\hline 1 & 0.5 & 0.5 & 0.5 & 0.24 & 2 & 1.74 & 87.00 \\
\hline 2 & 0.5 & 0.5 & 0.5 & 0.16 & 2 & 1.66 & 83.00 \\
\hline 3 & 0.5 & 0.41 & 0.5 & 0.42 & 2 & 1.83 & 91.50 \\
\hline 4 & 0.5 & 0.49 & 0.36 & 0.06 & 2 & 1.41 & 70.40 \\
\hline 5 & 0.5 & 0.5 & 0.48 & 0.17 & 2 & 1.65 & 82.50 \\
\hline 6 & 0.5 & 0.5 & 0.48 & 0.08 & 3 & 2.34 & 78.00 \\
\hline 7 & 0.5 & 0.5 & 0.46 & 0.37 & 2 & 1.83 & 91.50 \\
\hline Total & $\mathbf{3 . 5}$ & $\mathbf{3 . 4}$ & $\mathbf{3 . 2 8}$ & $\mathbf{1 . 5}$ & $\mathbf{1 5}$ & $\mathbf{1 2 . 4 6}$ & $\mathbf{5 8 3 . 9 0}$ \\
\hline Average & $\mathbf{0 . 5}$ & $\mathbf{0 . 4 9}$ & $\mathbf{0 . 4 7}$ & $\mathbf{0 . 2 1}$ & $\mathbf{2 . 1 4}$ & $\mathbf{1 . 7 8}$ & $\mathbf{8 3 . 4 1}$ \\
\hline Percentage of & 100 & 97.14 & 93.71 & 42.8100 & 83.05 & & \\
Average Score & & & & & & & \\
\hline \hline
\end{tabular}

vided into four steps of Polya (Understanding (0.5), Planning (0.5), Devising a plan (0.5), and Looking back (0.5)). There were seven items with total score 15 . Nearly all students applied step 1, 2, and 3 but less than 50 percent of all students did not apply step 4 (Looking back).

Students' progress considered from students' homework, worksheets, and teacher's reflection. From students' homework and worksheets, it revealed that students did not plan in advance. Because of researcher's suggestion about all steps after period 4, students showed awareness of planning in advance. The results were that the errors were decreased. From researcher's reflection, the planning step was emphasized together with using resources, strategies and control their thinking. Students read the problems many times to understand in some difficult problems. About 50 percent students showed no interest in checking the answer or reasonableness of the results.

\section{Students' Attitude towards Mathematical Problem Solving}

TABLE 4. Students' attitude in solving mathematics problems

\begin{tabular}{|c|c|c|c|c|c|c|c|}
\hline \multirow[b]{2}{*}{$\begin{array}{l}\text { Categories of } \\
\text { Students' Attitude }\end{array}$} & \multirow[b]{2}{*}{ Statement } & \multirow[b]{2}{*}{$\begin{array}{l}\text { Mean } \\
\mathbf{x}\end{array}$} & \multirow[b]{2}{*}{ SD } & \multirow[b]{2}{*}{ Level } & \multicolumn{3}{|c|}{ Total } \\
\hline & & & & & $\begin{array}{l}\text { Mean } \\
\bar{x}\end{array}$ & SD & Level \\
\hline \multirow{4}{*}{ 1. Positive feeling } & 1. I like solving mathematics problems because they are challenging. & 3.57 & 1.07 & Agree & & & \\
\hline & 2. I feel good when I can solve difficult mathematics word problems. & 4.60 & 0.77 & Strongly agree & & & \\
\hline & 3. I am confident that I can solve all mathematics problems. & 2.69 & 0.90 & Undecided & 3.66 & 1.18 & Agree \\
\hline & 4. I just want to get the answer by ignoring how to solve mathematics problems. & 3.77 & 1.11 & Agree & & & \\
\hline \multirow{5}{*}{ 2. Negative feeling } & 5. I give up easily when the mathematics problems are difficult. & 2.40 & 0.85 & Disagree & & & \\
\hline & 6. I do not like solving mathematics problems. & 2.23 & 0.88 & Disagree & & & \\
\hline & 6. I do not like solving mathematics problems. & 2.23 & 0.88 & Disagree & 2.45 & 0.94 & Dis-agree \\
\hline & 7. If I cannot solve a mathematics problem, I just ignore it. & 3.00 & 0.87 & Undecided & & & \\
\hline & 8. I am afraid of mathematics problems. 2.170 .95 Disagree & & & & & & \\
\hline \multirow{5}{*}{$\begin{array}{l}\text { 3. Applying Polya's } \\
\text { Four-Steps Schoen- } \\
\text { feld's behavior and } \\
\text { categories }\end{array}$} & 9. The first thing when I solve a mathematics problem is that I make myself unders- & 3.51 & 1.12 & Agree & & & \\
\hline & $\begin{array}{l}\text { tand easily by translating the problem into my own words drawing a picture or crea-. } \\
\text { ting a chart }\end{array}$ & & & & & & \\
\hline & 10. I often make a plan before solving a mathematics problem. & 3.31 & 0.96 & Undecided & 3.51 & 1.06 & Agree \\
\hline & 11. When I get stuck with a mathematics problem, I try other different ways. & 3.77 & 1.03 & Agree & & & \\
\hline & 12. I always verify the correctness of my solution after getting the answer. & 3.46 & 1.12 & Agree & & & \\
\hline
\end{tabular}


Table 4 showed results from questionnaire as follows: 1) High positive feeling towards mathematical problem solving $(\overline{\mathrm{x}}=3.66, \mathrm{SD}=1.18), 2)$ Low negative feeling towards mathematical problem solving $(\overline{\mathrm{x}}=2.45, \mathrm{SD}=0.94)$, and 3) High positive feeling in applying Polya's Four-Steps and Schoenfeld's Behavior Categories $(\overline{\mathrm{x}}=3.51, \mathrm{SD}=1.06)$.

\section{CONCLUSION}

The researcher implemented problem solving processes, Polya's Four-Steps and Schoenfeld's Behavior Categories in learning plans. According to the results of assessment, exercises, worksheets, homework and tests, it could be concluded that implementing the problem solving processes enhances students' mathematical problem solving. The results are in accordance with the expectation of researcher. The findings showed that students' scores of both tests were more than 70 percent of students passed as required by the researcher. The results of students' homework, worksheets, and teacher's reflection showed students' progress in mathematical problem solving ability. Most of the students applied Polya's Four-Steps and Schoenfeld's Behavior Categories while a great number of students did not apply looking back step and students are not confident in problem solving (belief system) that is consistent with the finding from questionnaire.

The researcher divided students' attitude into three categories as follows: 1) Positive feeling towards mathematical problem solving, 2) Negative feeling towards mathematical problem solving, and 3) Applying Polya's Four-Steps and Schoenfeld's Behavior Categories. In the first category, most students showed positive feeling to solve mathematical problems. In the second category, there were a few students who felt uncomfortable to solve mathematical problems. In the last category, there are quite a lot of students who applied Polya's Four-Steps and Schoenfeld's Behavior Categories.

\section{LIMITATIONS AND RECOMMENDATIONS}

The findings of this study are limited to the students of a single institute of Bangkok, Thailand. Thus, to generlize tehse findings more similar studies in different schools must be carried out.

According to integrating Polya's Four-Steps and Schoenfeld's Behavior Categories in solving problems in mathematics class, the researcher found that these strategies help students improve their mathematical problem solving and be more effective problem solver. Students have systematic thinking and problem solving skills. Moreover, Polya's FourSteps and Schoenfeld's Behavior Categories influence on students' positive attitude towards mathematical problem solving.

\section{REFERENCES}

Arreerard, P. 2009. Educational software development. Faculty of Information Technology, Rajabhat Maha Sarakham University, Thailand.

Ban-Har, Yeap, and Berinderjeet Kaur. 1999. Problem posing: An exploratory investigation. Paper presented at the 8th Southeast Asian Conference on Mathematics Education, Manila University, Quezon City, Philippines.

Bernardo, A.B.I. 1998. Analogical problem construction: A study on an instructional intervention for improving ana-

logical transfer in word problems. Paper presented at the 5th DLSU Mathematics Lecture Series.

Bureau of Academic Affairs and Educational Standards. 2008. The basic education core curriculum mathematics of the

basic education B.E. 2551. The Agriculture Co-operative Federation of Thailand, Bangkok, Thailand. URL: goo.gl/WbkuSu (accessed August 6, 2016).

Kopka, Jan. 2013. Umění řešit matematické problems. Praha, Slovakia.

Krulik, Stephen, and Rudnick, Jesse A. 1987. Problem solving: A handbook for elementary school teachers. Boston, MA: Allyn and Bacon. 
Likert, R. 1932. A technique for the measurement of attitudes. Archives of Psychology 140: 1-55.

National Council of Teachers of Mathematics (NCTM). 2000. Principles and standards for school mathematics. Reston, VA: National Council of Teacher of Mathematics.

National Council of Teachers of Mathematics. 1980. An agenda for action: Recommendations for school mathemat-

ics in the 1980s. Reston, VA: National Council of Teacher of Mathematics.

Polya, George. 1973. How to solve it. Princeton, NJ: Princeton University Press.

Schoenfeld, Alan H. 1992. Learning to think mathematically: Problem solving, metacognition, and sense-making in mathematics. In Handbook for research on mathematics teaching and learning, ed. Frank K. Lester, 334-370. New York, NY: MacMillan.

Schoenfeld, Alan H. 1986. Mathematical problem solving. Orlando, FL: Academic Press.

The institute for the Promotion of Teaching Science and Technology. 2008. The basic education core curriculum B. E. 2551 (A. D. 2008). Bangkok, Thailand. URL: goo.gl/udoYIS (accessed August 7, 2016).

— This article does not have any appendix. - 